\title{
31. LEG 25 RESULTS IN RELATION TO EAST AFRICAN COASTAL STRATIGRAPHY
}

Peter E. Kent, Technical Adviser, British Petroleum Company Ltd, Chairman, Natural Environment Research Council, London, England

\begin{abstract}
The sections penetrated during Leg 25 are notable for the stratigraphic gaps found, specifically in the middle Tertiary (Oligocene-Miocene), in the Paleocene, and in the Late Cretaceous despite their locations in deep water where deposition might have been expected to be continuous. Each of these gaps corresponds with either regression or tectonic events on land. Absence of Pliocene, less frequently documented, is in line with uplift of positive elements on the continental shelf.

Analysis shows that although the mid-Tertiary break (in particular) is widespread, the gap varies markedly in onset date and duration at different localities. All these breaks correspond with positive movements in various parts of the continental shelf, the mid-Tertiary ending at the time of early Miocene faulting and uplift, and the Late Cretaceous break ending about the time of major faulting in the coastal belt.

Evidence of shallow-water deposition which would precede or succeed actual emergence of the ocean bed is lacking; with one exception all the sequences associated with the lacunae are of deep-water facies. As we know from land sections, the supply of detritus was not interrupted for any significant length of time. The preferred explanation for the mid-Tertiary and endCretaceous breaks is that very limited sediment at the end of continental planation phases was concentrated in particular areas by current action, much of the sea floor being swept bare and locally eroded (a case of clastic starvation). Localized gentle upwarping may have accentuated the gap in some cases.

The DSDP results supplement the landward evidence that a seaway existed along the East African coast from Early Jurassic times and show that true ocean existed along the shelves at least as far back as early Late Cretaceous, probably beginning in Late Jurassic times.
\end{abstract}

\section{INTRODUCTION}

In reviewing the Leg 25 results, two points have to be checked: first, the validity of the dating; and second, the adequacy of the intermittent coring program to establish the sequences together with their lacunae. ${ }^{1}$ Comments on these points are made in the following paragraphs.

A review of micropaleontological data in the light of East African coastal faunas confirms the ship-based determinations in all the important particulars. These are low-latitude assemblages with a general similarity to those of the Lindi area (southern Tanzania). The diastems are firmly established in some, but not all, cases which have been quoted in preliminary accounts.

\footnotetext{
${ }^{1}$ The use of the term "unconformity" is avoided in this review because of the implication of angular discordance, evidence which is lacking in most of the cases considered. The terms "hiatus" or "diastem" are used here to avoid connotation for features for which the old term "non-sequence" applies (alternatively "disconformity").
}

It may be observed in passing that the use of the term "basement" for the basaltic ocean floor is somewhat tendentious in this area, where a comparable igneous series on the margins of the Mozambique Channel, forming the floor to the Tertiary and Cretaceous rocks, is known to overlie normal Jurassic and Karroo sediments. A similar relationship may apply in at least the marginal oceanic areas.

The drilling results are briefly reviewed on a regional basis, beginning in the north.

\section{REGIONAL APPRAISAL}

\section{Somali Basin}

Site 241 is located near the foot of the continental rise, 170 miles east of the coast on the latitude of the Kenya/Somalia border. Site 240 lies to the east, 500 miles offshore. These sites are near the refraction traverse of Francis et al. (1966) which demonstrated progressive easterly thinning of the coastal sedimentary column with apparent continuity of continental-type basement across the basin as far east as the Seychelles. 
In the adjoining coastal area, wells have produced some 3000 meters of mainly shallow-water Tertiary overlying Cretaceous, the latter (on seismic evidence) measuring up to 4000 meters (Walters and Linton, 1973). The Tertiary column, at least, continues to the edge of the continental shelf in the Lamu embayment, but the facies offshore has not yet been ascertained by drilling. Presumably, as in coastal Tanzania, the shelf was built out by progradation of shallow-water sediments involving contemporary large-scale subsidence (Kent et al., 1971). The Oligocene/upper Eocene strata were here regressive, marked by a wedge of continental sediments inland, and there is evidence for Cretaceous normal faulting which caused an absence of later Senonian and Paleocene deposition on structural highs (Walters and Linton, 1973).

Site 241 , drilled in 4504 meters of water, was located in the area where the refraction traverses indicated some $3 \mathrm{~km}$ of sediment. Drilling provided 470 meters of sediment from Quaternary to upper Oligocene and a 704-meter section extending from middle Eocene to Turonian-Cenomanian, entirely developed in a deep-water facies. The stratigraphic break corresponds with the regression known inland, but there is no evidence of any Tertiary/Late Cretaceous vertical movement (positive or negative) comparable in amplitude to those of the continental shelf.

It is interesting that the shallow-water foraminifer Eulepidina ephippoides occurs in the Aquitanian; this would not be expected to be autochthonous but could have been transported from the upper shelf.

Site 240 (Holes 240 and 240A drilled in the basin center in $5082 \mathrm{~m}$ of water) likewise shows an entirely deep-water facies, in this case, of Miocene to Recent sediments resting nonsequentially on Eocene. Graded bedding shows that turbidite transport of detritus from the African mainland extended this far $(800 \mathrm{~km})$ into the deep ocean.

At both sites, the dominant problem is the existence of gaps in the sedimentary sequence. At Site 241 , on the continental rise, these covered some 20 million years in the middle Eocene-late Oligocene and 17 million years in the Maestrichtian-early Paleocene. At Site 240, in the deep basin, a break spanned the early Miocene to middle Eocene interval. The circumstance that the mid-Tertiary gaps are not precisely coextensive adds to the complexity of the situation, which is discussed below.

Both holes at Site 240 reached tholeiitic basalt-"either extrusive floor or a very shallow intrusive." This is dated as no older than early Eocene from sedimentary inclusions. Based on evidence of the original seismic refraction traverse, this may not mark the base of the sedimentary series, although the date and condition of any underlying sediments (Karroo?) are highly speculative.

\section{Madagascar (Mascarene) Basin}

In the broad basin east of Madagascar, two sites were occupied. Site 239 is 180 miles east of the coast in 4971 meters of water; Site 245 is some 700 miles to the south of this in 4857 meters of water.

Site 239 first penetrated a tripartite sequence of terrigenous silt and clay $(158 \mathrm{~m})$ extending back into the middle Miocene, resting on a fine-grained sequence with limestone in the upper part and having some turbidite and nanno-ooze lithology below, dated as late Oligocene to Late Cretaceous, with a stratigraphic gap covering the middle Eocene to later middle Paleocene. The basal sediments are Upper Cretaceous, Maestrichtian, or possibly Paleocene, resting on extrusive tholeiitic basalt.

The change in lithology in the middle Miocene is ascribed by the shipboard scientists to uplift of the source areas. The eastern coast of Madagascar, in fact, shows only a narrow belt of Cretaceous (Senonian) without accompanying Tertiary rocks-compatible with later (and probably intermittent) uplift, independently established by the erosional history (Dixey, 1960).

Site 245 (twin holes) was located 200 miles northwest of the Southwest Indian Ridge crest. The first 63 meters has been assigned to the middle Miocene, with a stratigraphic break separating this from upper Eocene, but in the interval are 35 meters of unfossiliferous sediment which could represent the Oligocene (compare thickness at Site 241). The Eocene and Paleocene are deep-water sediments, with a basal black high-manganese stratum dated as Danian, overlying tholeiitic basalt.

This date is compatible with the inferred mid-ocean ridge history of the southwest Indian Ocean; it is, however, not significantly different from that of the basaltic basement at Site 239 which is in a rather different setting.

The paleontologic shipboard report comments that "all the mixed samples from the Quaternary and Pliocene of the Mascarene Basin show natural mixing of deep and shallow water material, besides the benthonic foraminifera already named, residues of bryozoans, echinoderms, mica and quartz..." Further, there is an anomalous occurrence of medium-shelf-depth benthonic forms in the middle Eocene at Site 245. The latter could relate to depth change in relation to the mid-ocean ridge mechanism, but the Neogene occurrences require something different, perhaps a formerly more extensive shelf east of Madagascar. Continued uplift of the eastern part of the Madagascar block (shown by the erosional history) might be associated with late subsidence of the adjoining ocean floor, and Dixey (1960, p. 267) suggested that the polycyclic uplift of this coast was associated with a major offshore fault.

As indicated by records from these two sites (a very limited basis for synthesis), the Mascarene Basin came into existence in the Late Cretaceous. It has been largely a deep-water area of slow sedimentation far from major sources of detrital sediments, but anomalous occurrences of undoubted shallow-water material suggest that there has not been an entirely simple history of continuous deep-water conditions over the whole width of the basin.

\section{Mozambique Channel and Mozambique Basin}

Three sites were occupied in the Mozambique Channel. Site 242 in 2275 meters of water on the Davie Ridge is almost midway between Madagascar (Cap St. Andre) and the mainland coast. Sites 243 and 244 are nearer the Madagascar side of the channel opposite the Zambesi River but penetrated only gravels, raising problems of sea-floor sediment transport but not throwing light on the longer term history.

Further south, Site 248 is located in the Mozambique Basin in 4994 meters of water; Site 249 on the flanking Mozambique Ridge is in 2088 meters of water. 
Coring at Site 242 showed continuous deep-water ooze (including a good representation of the Oligocene) resting on compacted Eocene chalk. It provides a minimal age for this part of the Mozambique Channel, showing it to be a relatively old feature and to have been deep ocean continuously through the Tertiary. The location may not be typical of the whole channel, however, since it lies opposite basement highs with attenuated 'stratigraphic sequences on both the African mainland and the Madagascar coast, on a swell separating the Majunga/ Morondava basins in Madagascar and the Tanzania/ Mozambique basins on the mainland, which has been postulated to be continuous beneath the submerged area. Elsewhere, longer sequences might be expected.

At Site 248, the drill penetrated 150 meters of acoustically transparent silty and clayey nanno ooze with granitic and other continental detritus (early and middle Pleistocene), a grayish-green clay and silt (Pliocene), on well-stratified quartz sand and silt with a shallow-water benthonic fauna (middle to early Miocene). An unconformity is postulated between this unit and underlying Eocene and Paleocene, but this coincides with a 38-meter uncored interval and there could be representatives present of some of the unidentified beds. The Paleocene rests on pre-Danian porphyritic basalt (this is stated by P. Lehner of Shell to be in seismic continuity with the Early Cretaceous traps of Mozambique).

The hole thus shows a phase of interrupted or very slow deposition in the later Eocene, Oligocene, and early Miocene followed by a flood of terrigenous material with shallow-water organisms. This peneplain was near perfection and undisturbed, followed by renewed heavier deposition associated with early Miocene faulting and/or epeirogenic uplift (see below).

Site 249 is located near the crest of the Mozambique Ridge. Pleistocene ooze measured only 1.7 meters (Pliocene was absent), resting on 176 meters of upper and late middle Miocene nanno ooze. This directly overlies 115 meters of nanno chalk of Late Cretaceous age (Maestrichtian to late Campanian) itself resting unconformably on 123 meters of dark-colored, iron-rich Cenomanian/Turonian (or older) siltstone. Cross-lamination and glauconite are reported in this lowest series which rests on glassy basalt, notably weathered.

Here on a positive structure, a suspected microcontinental unit, three stratigraphic breaks are present and clearly established, but only in the lowermost sediments is there any indication of shallow-water conditions. This history is consistent with vertical block faulting broadly contemporary with movements known in continental Africa.

The stratigraphy of Madagascar is well known. The island occupies the eastern part of the sedimentary basin, open to the west, which developed during Karroo (late Carboniferous) and continued to subside with minor interruptions through the Mesozoic and early Tertiary (Besairie, 1972; Blant, 1973). In coastal Mozambique, we are indebted to Robert M. Sanford, Hunt International Petroleum, for the information that at the latitude of Beira, Tertiary beds-in continuous sequence-measure almost 15,000 feet and rest upon possibly as much as 20,000 feet of Cretaceous and Jurassic, with indications of an evaporite-bearing Karroo basin beneath (compare southern Tanzania). The very thick Tertiary, probably also the thick Mesozoic, continues to the edge of the continental shelf and probably thins progressively beyond. The Karroo may be limited to the continental area.

The three holes of Leg 25 penetrating pre-Pleistocene beds lying to the north or south of the Mozambique strait show no direct relationship to these long sedimentary columns. We do not know whether Jurassic and older sediments underlie the oceanic basalts as they do the equivalent basic extrusives on land further north, but the Cretaceous sections establish that the Strait of Mozambique is relatively old, and with the continuity of the basalts from the Mozambique land area across the channel, support those who hold that Madagascar has been in approximately its present position for-a relatively long period-apparently before the main sea-floor spreading episode.

\section{Madagascar Ridge}

Two adjacent sites, 246 and 247, were occupied on the Madagascar Ridge about 500 miles south of Madagascar. These are in much shallower water than other sites, Site 246 being in 1030 meters and Site 247 in 944 meters depth, on a ridge which forms a topographical southerly continuation of Madagascar (micro-continent?) but which is also related to the magnetic anomaly spreading pattern.

The section at Site 246 showed 124 meters of ooze dated as Quaternary to late Miocene. There is, however, an element of doubt about the downward time range of this unit. for a mixed assemblage of early Miocene age is reported, and there is a reference to "technical mixing" in addition to original mixing. Additionally, there is an independent view that a late Oligocene date would be an equally valid interpretation of the paleontological evidence. The hiatus could in consequence be somewhat shorter than the initial reports suggest. Nevertheless, at least the earlier Oligocene as well as most of the Eocene are absent, and the upper unit rests on glauconite-rich volcanic sandstone and tuff.

This section (Site 246) is notable in that the older Tertiary (Units II and III) was deposited in relatively shallow water $(300 \mathrm{~m})$, the Miocene in deep water $(1000 \mathrm{~m})$. This is a unique demonstration of vertical subsidence independent of sedimentation.

If this area were considered as a possible submerged continuation of Madagascar, the sequence would be interpreted as lower Tertiary transgressing onto the Lower Cretaceous volcanic series, but the solution may be less simple than this.

\section{STRATIGRAPHIC GAPS}

When deep-sea drilling was first discussed, it was widely assumed that sections in the deep ocean would show continuous unbroken sequences, with continuous records of organic evolution. Reality is decidedly different and Leg 25 provides outstanding examples of discontinuous deposition (Figure 1), the extent of the missing beds being listed as follows:

\section{Somali Basin}

Site 241-late Oligocene/early Eocene; middle

Paleocene/late Senonian (probably Campanian)

Site 240-probably early Miocene/early Eocene 


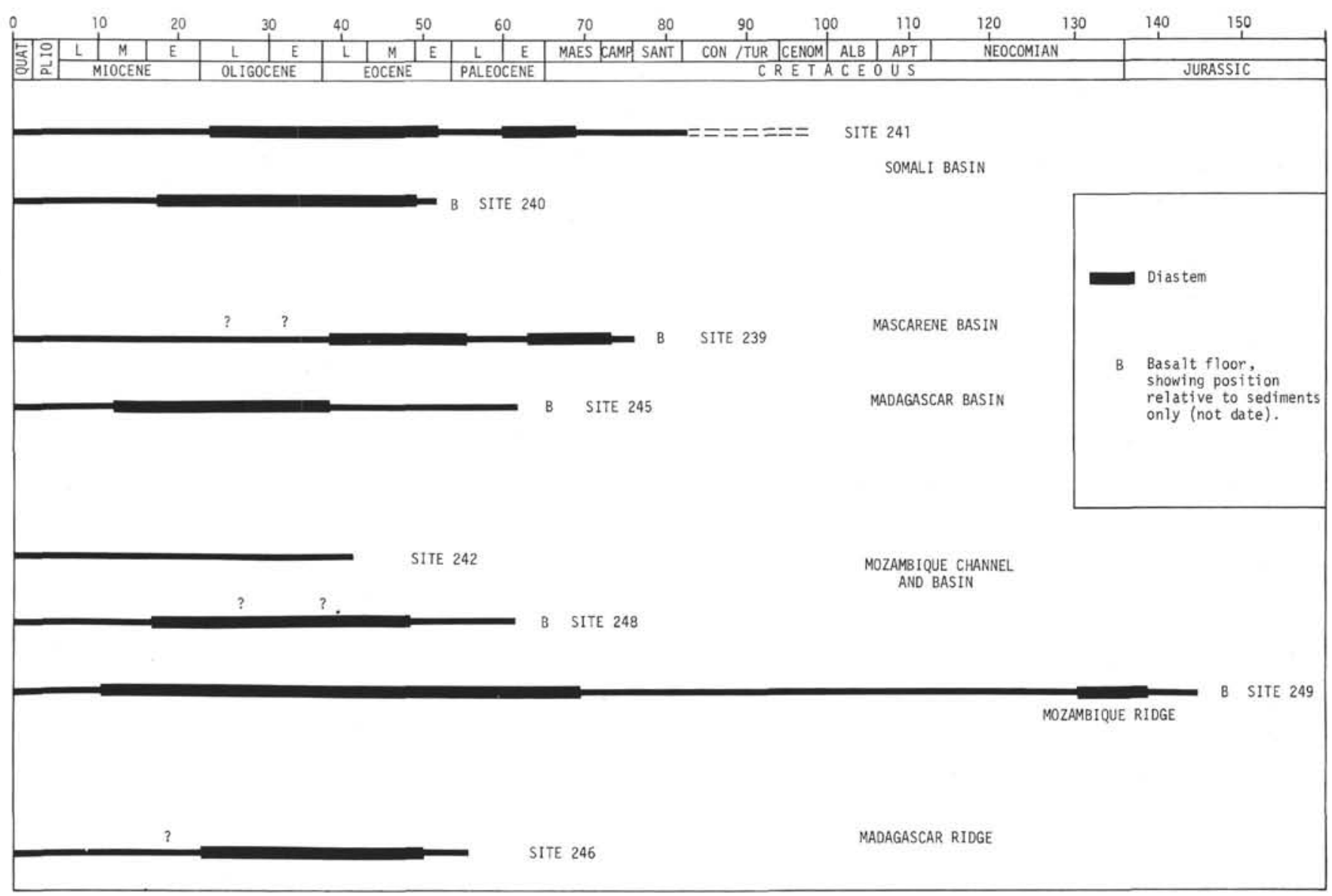

Figure 1. Oceanic stratigraphic breaks.

\section{Mascarene Basin}

Site 239-late Eocene/late Paleocene; early Paleocene/ early Maestrichtian or late Campanian

Site 245-probably middle Miocene/late Eocene(?)

Mozambique Channel and Mozambique Basin

Site 242-(continuous back to late Eocene)

Sites 243, 244 - (no data)

Site 248-possibly early Miocene/middle (?) Eocene

Site 249-Pliocene (?); middle Miocene/late Maestrichtian; late Campanian/early Cenomanian; possibly early Aptian or Barremian/Neocomian

\section{Madagascar Ridge}

Sites 246, 247-possibly early Miocene/early Eocene; alternatively Oligocene/early Eocene

Minor uncertainty exists at Site 248 where unfossiliferous beds could represent part of the missing strata and at Sites 246 and 247, where the paleontological data leave open an alternative dating.

Some of the sites were located on positive structures which may have undergone uplift, more or less contemporary with mainland movement; these include Sites 246 , 247, and 249. Site 242 on the Davie Ridge, however, showed continuous deposition, and gaps in cases such as at Sites 240 and 239 cannot be explained in this way.

The explanation has to be related to the following aspects of mainland geology (Figure 2):

1) The late Mesozoic shows regressions in the Early Cretaceous (Neocomian/Aptian) and, briefly, in the early Late Cretaceous (Turonian).
2) Extensive peneplanation occurred inland in phases ending at end-Jurassic, end-Cretaceous, and "mid-Tertiary."

3) A major transgression of coastal areas of both the mainland coast and of Madagascar took place in the late Oligocene/early Miocene; limestones became the dominant shelf lithology.

4) An important phase of faulting took place in the Miocene, as demonstrated in Mozambique (Flores, 1973) and in Tanzania by a contemporary marine breccia at Lindi (Kent et al., 1971; Kent and Perry, 1973). The dating of this event has been revised and is now established as middle Miocene.

5) Heavy clastic deposition occurred in the later Miocene and Pliocene, with episodes of uplift and faulting in late Pliocene and Pleistocene particularly affecting positive units.

No one of these factors suffices to explain the complex history of oceanic sedimentation. The Turonian gap, in particular, is known in both mainland regression and in the ocean, but no common mechanism for the two areas is here suggested.

With the solitary exception of Sites 246 and 247, where the older beds (Eocene) are in shallow-water facies, a universal aspect of the Leg 25 evidence is the absence of shallow-water deposits before or after the stratigraphic breaks, even though, in some cases, there is an admixture of shallow-water-detrived material (faunas and minerals) in the deep-water sediment. It follows that (except possibly at Sites 246 and 247) the breaks are not due to exposure of 


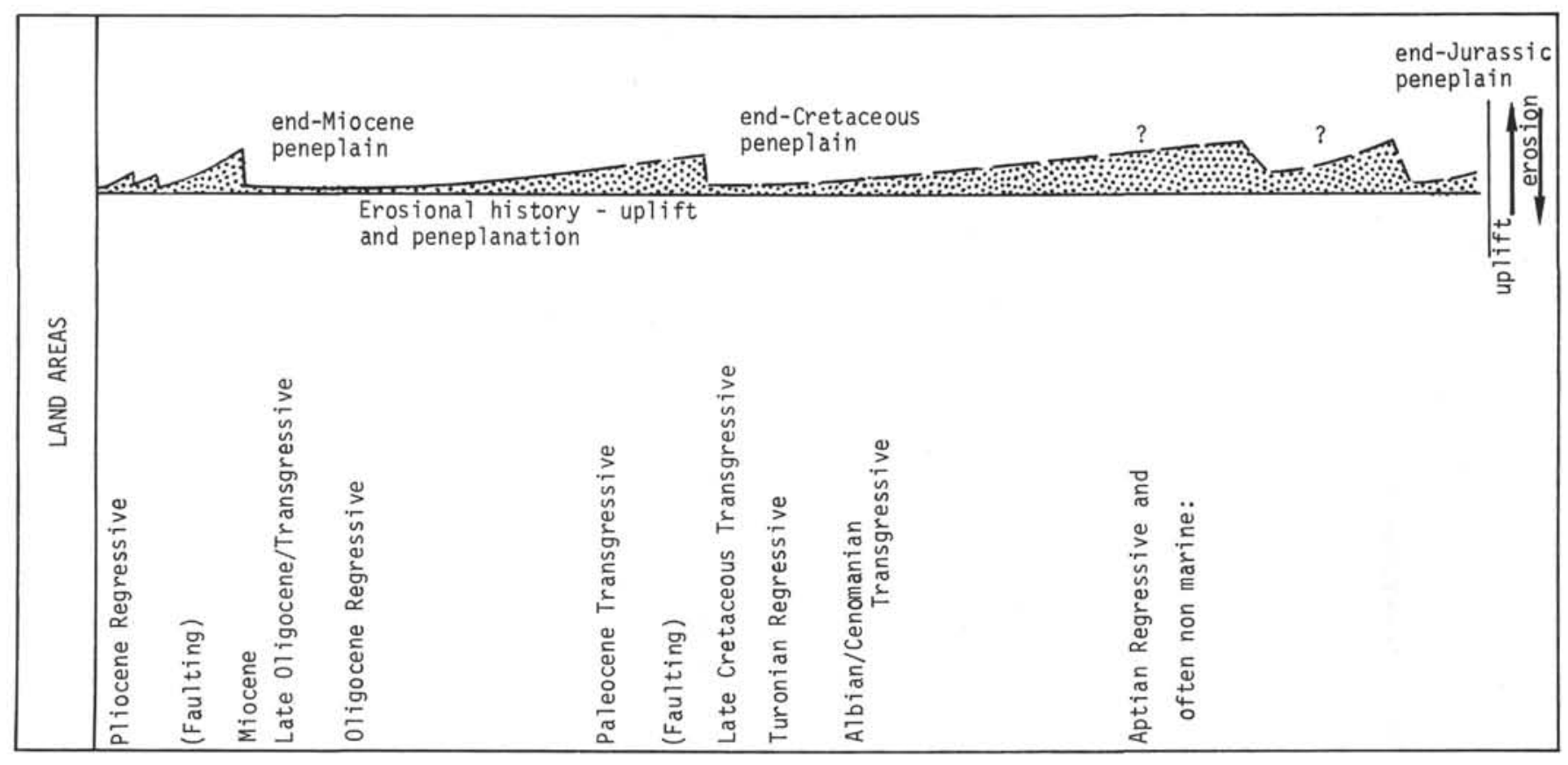

Figure 2. East African Events: uplift and peneplaination; regression, transgression, and faulting.

the sea floor (as might be the case on a shelf), but to absence of deposition under deep water. Analogies with the known lacunae known on land, therefore, have limited application.

Regional total cessation of sediment supply can also be excluded. The missing beds are well represented locally on the East African coast, some of them developed to great thicknesses. Erosion of the African mainland and of Madagascar continued to provide detrital material throughout the whole of the Cretaceous and Tertiary.

The distribution of diastems as now identified, taking account of the date revisions by Sigal (this volume), is less regular than the preliminary reports suggested. The most striking synchronism is the common absence of Oligocene and early Miocene, which is coincidental with the advanced development of the "Miocene peneplain" on land. Absence of Eocene and part of the Paleocene (Sites 239 and 249) is less easily correlated with landward events, but the Late Cretaceous/early Paleocene gap (Sites 241 and 249) could be related to the "end-Cretaceous peneplain" development.

In these cases it seems likely that advanced peneplain development had progressively reduced the supply of erosional products and that this was further checked by transgression so that coastal sediment traps were able to accommodate almost all the outgoing clastics. This would particularly apply during the Oligocene/early Miocene, when dominance of limestones on the coast (except near major river mouths) reflects a limited supply of detritus. Faulting, probably extensive both on the coast and inland, took place in the middle Miocene and was associated with widespread uplift leading to resumption of a supply of detritus. Earlier, the sub-Paleocene unconformity in Kenya may reflect a comparable episode of faulting and uplift terminating peneplanation.

The main control of the deep-sea stratigraphic breaks thus appears to be sediment starvation controlled by events on land. The irregularity of the timing of the gaps requires a further factor, and it seems likely that on the general lack of sediment was superimposed control by current action, perhaps related to local warping of the ocean floor, so that some areas received a meager detrital supply while others were swept bare. This may have been the dominant factor in the case of the localized Eocene/Paleocene gaps.

The deep-sea sediment history only goes back to the Lower Cretaceous at one location-Site 249 on the Mozambique Ridge, where there is an early Aptian or Barremian/Neocomian break. This may be a special case of local uplift, since the site is on a fault feature and may be related to the earth movements, which on land (Madagascar and Tanzania), produced widespread Early Cretaceous regression.

\section{HISTORY OF THE WESTERN INDIAN OCEAN}

The early history of the development of marine conditions has been traced elsewhere (Kent, 1972). The continental margin initially broke down in Karroo times, movements probably beginning in the late Carboniferous but involving full marine conditions in the Permian of Madagascar, thick evaporites (ocean connected basins?) in the Permian-Triassic of Tanzania and possibly also in Mozambique and South Africa. Marine faunas which spread southward from Tethys in the Early Jurassic are known in coastal Somalia, inland northern Kenya, and in northern Madagascar. This transgression became general in the Middle Jurassic when coastal Kenya, Tanzania, and western Madagascar were also invaded by the sea. From then on, a normal shelf regime typified the entire East African coastal region.

Whether the Jurassic marine episode related only to an epicontinental sea, with deep ocean developing later, is unknown. Some of the DSDP penetrations ended at basalt, Eocene at Site 240, earliest Tertiary at Sites 245 and 248, 
Maestrichtian at Site 239, and Neocomian at Site 249. The existence of sediments beneath is conjectural. Site 241 showed that deep-oceanic sedimentation began as early as Cenomanian, and Site 249 showed that deep-oceanic sedimentation began as early as Neocomian, but drilling evidence extends no further back in history.

Seismic evidence, however, supplements the direct evidence. At Site 241, at the foot of the continental rise, the drill penetration amounted to 1174 meters, but the sedimentary column is believed to be $3.7 \mathrm{~km}$ thick overall (Francis et al., 1966). With an early Late Cretaceous date for the bottom of the hole, this implies a sedimentary history probably extending back into the Jurassic, with a fair presumption that true oceanic conditions were established by Late Jurassic times.

Further south, the paleoposition of Madagascar has been a matter of controversy, although opinion has now swung against drift from a former position alongside Kenya (Flores, 1970; Tarling, 1972; Blant, 1973, listing various hypotheses; Kent, 1972). Stratigraphy of the lands bordering the Mozambique Channel indicates that this was a seaway of fluctuating extent by middle or early Late Jurassic; euxinic conditions were established in the Early Cretaceous (Flores, 1970). DSDP drilling shows that it was not only a seaway but was of oceanic depth by the Eocene (Site 242) and Early Cretaceous (Site 249). Whether this marked the initiation of the ocean in these latitudes is conjectural, for comparably located Albian to Turonian basaltic lavas on both sides of the channel are underlain by more sediments, and very much deeper penetration will be required to provide the whole story.

\section{ACKNOWLEDGMENTS}

Warm thanks are due to Mr. Robert M. Sanford of Hunt International Petroleum for making available unpublished information on the Mozambique continental shelf. Thanks also to Dr. W. J. Clarke and Dr. R. Walters of the British
Petroleum Company's research station, Sunbury, for advice on microfaunal dating.

\section{REFERENCES}

Besairie, H., 1972. Géologie de Madagascar, I. Les Terrains Sedimentaires: Annales Géologiques de Madagascar, v. 35, Tananarive, Madagascar.

Blant, G., 1973. Structure et paléogéographie du littoral méridional et oriental de l'Afrique. In Blant, G. (Ed)., Sedimentary basins of the African coasts, Pt. 2: south and east coast: Paris (Assoc. African Geol. Surveys), p. 193-233.

Dixey, F., 1960. The geology and geomorphology of Madagascar, a comparison with eastern Africa: Quart. J. Geol. Soc. London, v. 116, p. 255-268.

Flores, G., 1970. Suggested origin of the Mozambique Channel: Geol. Soc. South Africa Trans., p. 1-16.

1973. Mozambique and Zululand. In Blant, G. (Ed.), Sedimentary basins of the African coasts, Pt. 2: south and east coast: Paris (Assoc. African Geol. Surveys).

Francis, T. J. G., Davies, D., and Hill, M. N., 1966. Crustal structure between Kenya and the Seychelles: Phil. Trans. Roy Soc. London, Series A, v. 259, p. 240-261.

Kent, P. E., 1972. The Mesozoic history of the east coast of Africa: Nature, v. 238, p. 147-148.

Kent, P. E., Hunt, J. A., and Johnstone, D. W., 1971. The geology and geophysics of coastal Tanzania; Inst. Geol. Sci., London, Geophys. Paper, No. 6.

Kent, P. E. and Perry, J. T. O'B., 1973. The development of the Indian Ocean margin in Tanzania. In Blant, G. (Ed.), Sedimentary basins of the African coasts, Pt. 2, south and east coast; Paris (Assoc. African Geol. Surveys), p. 113-131.

Tarling, D. H., 1972. Another Gondwanaland: Nature, v. 238, p. 92-93.

Walters, R. and Linton, R. B., 1973. The sedimentary basin of coastal Kenya. In Blant, G. (Ed.), Sedimentary basins of the African coasts, Pt. 2: south and east coast; Paris (Assoc. African Geol. Surveys), p. 133-158. 